\title{
Factors Underlying the Adoption of Online Banking by Mexican Consumers
}

\author{
Somkiat Mansumitrchai \\ Faculty of Business, ALHOSN University, Abu Dhabi - UAE \\ Tel: 971-2407-0525 E-mail: somkiatm@yahoo.com \\ Husam-Aldin N. AL-Malkawi (Corresponding author) \\ Faculty of Business, ALHOSN University, Abu Dhabi - UAE \\ P. O. Box 38772, Abu Dhabi, United Arab Emirates \\ Tel: 971-2407-0568Ｅ-mail: h.almalkawi@gmail.com
}

Received: March 17, $2011 \quad$ Accepted: April 27, $2011 \quad$ doi:10.5539/ijbm.v6n9p155

\begin{abstract}
Although Mexico is considered one of the most important emerging markets in global business, there is little knowledge about the adoption of internet banking in Mexico. Thus, the purpose of this study is to examine the factors underlying the adoption characteristics of internet (online) banking by Mexican consumers, which will benefit both academics and financial institutions. The paper uses both qualitative and quantitative approaches for research methodology. The qualitative method is used to gain insight into how consumers value online banking by interviewing both adopters and non-adopters of internet banking (hereafter IB). Then, a questionnaire is developed to include thirty-nine questions. The paper utilizes Factor Analysis to identify the characteristics of the adoption and the Analysis of Variance (ANOVA) to examine the differences between adopters and non-adopters' attitudes toward some attributes of the adoption. The results from Factor Analysis suggest eight characteristics of the adoption, namely difficulty, trust, compatibility, third party concerns, human contact, social influence, security, and computer proficiency. Analysis of Variance shows that adopters and non-adopters differed on their attitudes toward four attributes of the adoption: difficulty, trust, compatibility and human contact. Comparing the attitudes of adopters and non-adopters with the issues of security and third party concerns, the study found no significant differences. An interesting finding was that human or physical contact was considered important for non-adopters, showing the weakness of online banking. A discussion of the results and the implications for bank managers were included in the study.
\end{abstract}

Keywords: Internet banking, Adoption, Consumers, Factor analysis, Mexico

\section{Introduction}

Digital technology has become an important factor for both industrial and service sectors, and it is considered as an external force that can affect a firm's success. In the service sector, many commercial banks have adopted internet banking (IB). Bank customers can now perform many transactions on the banks' websites such as balance inquiries, money transfers to third parties, payroll deposits, cheque orders, and bill payments. These transactions have already been listed in online banking literature (Chou and Chou, 2000; Karjaluoto et al., 2002).

There have been a growing number of studies of the diffusion of IB lately. Studies of the adoption of IB are of interest to both academics and practitioners. For academics, whether the adoption characteristics of consumers in developing countries are systematically identified is of interest. For senior bank management, knowing customers' opinions toward internet banking helps management understand their customers better, which will help increase customers' satisfaction.

The studies of diffusion innovation of IB have been explored by many scholars using the scholarly work of Rogers (1962) on diffusion innovation. Previous studies (e.g. Gerrard and Cunningham, 2003) have identified major factors of the diffusion process of online consumers based on Rogers. The studies of the adoption of IB have been widely studied for developed countries (e.g. Sathye, 1999; Karjaluoto et al., 2002; Mattila, et al., 2003; Pikkarainen et al., 2004; Waite and Harrison, 2004; White and Nteli, 2004; Lassar et al., 2005, among others), advanced developing countries (e.g. Gerrard and Cunningham, 2003; Wang et al., 2003; Akinci et al., 2004) and in developing countries (Gurau, 2002; Rotchanakitumnuai and Speece, 2003; Eriksson et al., 2005; Wallsten, 2005). 
As compared to the number of studies of IB in developed nations, the number of studies of electronic (e) banking in developing countries is quite limited. This must get the research scholars' attention. The lack of knowledge about the adoption characteristics of consumers in developing countries such as Mexico is crucial for banks. Also, there was a lack of knowledge about the adoption characteristics among Mexican consumers. Thus, the study of the adoption of e- banking practices of Mexican consumers is a primary task of this research, helping to extend an understanding of the diffusion process from previous studies and from traditional study by Rogers (1962).

\subsection{The Mexican context}

The number of internet users in Mexico has significantly increased over time. For instance, at the end of 2004 there were about 14.9 million internet users (14.3\% of total population) in Mexico. This number reached to 20.20 million (19.2\% of total population) in 2006 and 30.6 million $(27.2 \%$ of total population) in 2010 (see www.nternetworldstatistic.com).

All major banks in Mexico provide online banking services to their clients. In 2003 the data shows there were 4.5 million adult internet users, of which $80 \%$ (3.5 million) of the users held a bank account. About $70 \%$ or 2.5 million people conduct banking operations through online banking (Business News Americas, 2003). Online banking operations at Mexico's largest bank, Bancomer, a subsidiary of the Spanish financial group BBVA, represent $33 \%$ of the six million monthly online transactions undertaken on the country's banking portals. According to Bancomer, about $50 \%$ of its internet clients use the website for financial transactions. The financial transactions conducted online include third-party account transfers (39\%), payroll payments (29\%), transfers between the accounts of individuals $(10 \%)$, tax payments $(8 \%)$, bill payments $(8 \%)$, and money transfers between banks (4\%) (Corporate Mexico, 2003).

\subsection{Service Charges for Online Banking}

Many Mexican banks began to charge their clients for online services after 2004. BBVA Bancomer has charged its customers 25 pesos a month for the service since April 2004. In January 2005, a second major bank Banamex, a subsidiary of Citibank, also began charging its customers for online banking, ranging from 120 pesos to 250 pesos yearly. The bank had offered its online service for free for the previous four years. Although service charges may reduce the number of customers who plan to use IB because they are considered an extra cost to the bank's customers, the rates charged have not inhibited online customers willingness to sign up for the service in Mexico (Business New Americas, 2005).

\section{Conceptual Framework and Prior Research}

The preceding section shows that online banking has received much attention from both academia and industry. Therefore, the conceptual framework presented in this section identifies the attributes of the adoption of online banking by Mexican consumers. Rogers (1995) identified four elements (innovation, communication channels, time, and the social system) of the diffusion process. According to his study, these four elements were identifiable in every diffusion research study. Rogers explained innovation as an idea, practice or object that was perceived as new by an individual or other unit of adoption. The perceived newness of the idea for the individual determined his or her reaction to it. In addition, the newness aspect of an innovation may be expressed in terms of knowledge, persuasion, or a decision to adopt. Further study by Black et al. (2001) also noted that the perceived attributes of an innovation could affect the rate of adoption.

Rogers also explained further in his study that it should not be assumed that the diffusion and adoption of all innovations were necessarily desirable. Some innovations may be desirable for one adopter in one situation but undesirable for another potential adopter or non-adopter in a different situation. This observation was been hypothesized by many previous diffusion research studies. Studying characteristics of online banking adoption in Singapore, Gerrard and Cunningham (2003) found that online banking adopters and non-adopters had different perceptions of adoption characteristics such as social desirability.

One of the important research questions addressed by traditional diffusion studies was how perceived attributes of an innovation, such as its relative advantage, compatibility, complexity, trialability, and observability affected the rate of adoption (see Rogers 1983). Previous studies show that these attributes were important for the adoption of online banking. Gerrard and Cunningham (2003) establish that online banking adopters perceived the online service from banks to be more convenient, less complex and more compatible. Waite and Harrison (2004) display that the expectations and perceptions of online retail banking information from consumers were high on the relative advantage and complex attributes such as convenience and ease of use. Another study by Waite and Harrison (2002) about the expectations of online information provided by bank websites shows that consumers ranked the relative advantage attributes (ease and speed) the first and the second most important attributes.

Previous studies demonstrate that perceived risk and security were important attributes affecting the rate of adoption. Sathye (1999) studied the adoption of IB in Australia and found that security concerns about IB also affected the adoption of online banking. Using the Technology Acceptance Model (TAM) to examine consumer acceptance of online banking in Finland, Pikkkarainen et al.,(2004) pointed out that the security impacted online 
banking adoption. Cooper (1997) also found the risk played an important role from a consumer opinion perspective in the adoption of innovation. White and Nteli (2004) studied IB in the U.K. and the results illustrate that the security of a bank's website was seen to be significantly more important than the other attributes, and that security was still the number one issue in consumers' minds when considering IB. Many other studies have identified risk and security as important attributes for the adoption of technological innovation (e.g. O'Connell, 1996; Daniel, 1999; Polasik and Wisniewski, 2009).

Reference groups or social influence are often found to affect consumer behavior (Fishbein and Ajzen, 1975; Bagozzi, 2000). Social influence is also an important attribute that affects the adoption of innovation. Rogers (1983) stated that all innovation carries some degree of uncertainty for individuals, who are typically unsure of new innovation's result and thus feels a need for social reinforcement their attitude toward the new idea. Individuals want to know that their ideas are on the same track as that of their peers. Karjaluoto et al., (2002) suggest that reference groups strongly affected attitude and behavior toward online banking.

\section{Methodology}

There were two phases of the research method used in this study qualitative and quantitative.

\subsection{Phase 1: Qualitative Method}

The qualitative method was used to gain insight into how consumers value online banking by interviewing both adopters and non-adopters of IB. This approach allowed us to understand the perception of consumers toward IB, and also it helped to identify some latent variables which might affect the adoption of IB. This method also helps identify possible factors not captured by previous studies. The same method was used for non-adopters.

\subsubsection{Opinions of adopters}

Because the research interest focused on working people who were more likely to adopt online banking, all of the adopters interviewed for this study were employed. Three different groups provided similar responses in reference to perceptions about online banking. The most common comment made by adopters was on the basis of compatibility as expressed by the following comments; "Internet banking is compatible with my lifestyle"; "Using Internet banking fits into my working style"; "I liked innovation and I was satisfied with Internet banking"; and "Internet banking enables transactions to be conducted at home".

Other comments made by adopters about using online banking involved practicality and ease of use. Some online banking adopters said "Internet banking was an easy way to conduct banking transactions"; "Using internet banking was practical and was not complicated at all"; "I could perform my bank transactions on the web easily"; and "The web page was easy for me to do the transactions."

Additional comments from adopters were about the convenience and the benefits of using online banking; "It was fast and comfortable to do transactions online"; "It saved my time because I did not need to go to the bank"; "It was convenient and cheap for me to do transactions at home"; "I could check my bank account any time I wanted online"; and "Online banking was open 24 hours a day and it was convenient for me."

However, interviews showed that online banking still has many weaknesses from the users' point of view. Most adopters interviewed were still concerned with the online banking process which they were using. They were primarily concerned about the ability of third parties to gain access to their information.

The following comments demonstrate this concern; "A third-party may be able to access my financial details on the internet"; "My financial data might be passed on to other companies in the bank group"; and "I was afraid that hackers may be able to gain access to my accounts". Other comments were "I am worried about the security of an internet bank"; "PINs obtained by fraud might allow access to my internet account"; "I believed that Internet banking was still not quite secure but I used it anyway"; and "I was worried about the security of an internet bank".

\subsubsection{Opinions of non-adopters}

The greatest concern expressed by most non-adopters was security. Many non-adopters commented on this; "Online banking was not secure"; "Because of the security issue, I would not use online banking"; "Matters of security had an influence on my decision to use internet bank"; "I was worried about the security of an internet bank"; "Doing transactions at the bank was more secure"; and "I preferred to do transactions at the bank because it was more safe than to do transactions online".

Most of the non-adopters interviewed mentioned trust and most of the non-adopters decided not to use online services because of the trust issue. The following were comments made by non-adopters; "I did not trust the ability of the bank to protect my privacy"; "I did not trust the technology used at the bank for its online service"; "My friend who used the online banking still did not trust the technology of the bank"; and "I did not trust online banking and there was no need to use it".

Another issue for non-adopters was difficulty. Although most non-adopters already had experience using computers and the internet, they felt that using online banking was difficult. The following were comments about this issue; "Internet banking web pages were confusing"; "Using Internet banking was difficult to understand"; 
Internet banking transactions involved complex procedures"; I found that internet banking was a difficult way to conduct banking transactions"; "For me, it was complicated to use online banking"; "I felt that using online banking was difficult because I had to key in excessive information such as a password anytime when I wanted to use it"; and "Using online banking requires many efforts".

Most of the non-adopters mentioned the security issue. They were also concerned about third-party intrusions. Like adopters, non-adopters made similar comments related to the issue of security and third-party concerns. The following were their comments; "I felt that using online banking was not safe"; "I was afraid that someone might access my bank accounts"; "Because of the security issue, I did not use online banking"; "It was dangerous to use online banking because someone could access to your bank account"; "I was worried about the security of internet banking"; and "My financial data might be passed to other companies".

Another issue mentioned by the non-adopters was the physical contact. Some non-adopters commented that human contact should be a norm for the service at a bank, and online banking lacked this element. These were the comments. "Face to face interaction was important for bank services"; "I preferred to go to the bank because I could meet the staff"; "I preferred to do transactions at the bank myself"; "Online banking did not offer personal help when I needed it".

\subsection{Phase 2: Quantitative Method}

Questions were developed based on the focus groups from the qualitative phase. Some questions also were derived from previous studies in the literature review process. The interviews and prior studies suggested forty six questions. However, the number of the questions was reduced because some questions were not relevant to the local environment. The pilot test of the questionnaire was used to identify any possible errors and was used to ensure validity. Comments and suggestions from the respondents were recorded and the corrections were made at the final stage.

The final questionnaire included thirty-nine questions. The sample group included only working people who were more likely to use online banking. Employed individuals were also a target segment for online banking. The questionnaires were sent to these people who were working in organizations such as universities and offices. A non probability method was used, thus the survey was conducted on the convenience of the base sample. Although this method does not make this study representative of all online users in Mexico, the sample units, working people, are nevertheless a population of research interest. About eight hundred questionnaires were sent to the target sample and 395 questionnaires were returned. Thus, the response rate was 49.38 per cent. Table 1 provides the profile of the respondents and their internet uses.

\subsubsection{Factor Analysis}

Reliability was assessed to ensure the degree of consistency among measurements of the variables. Using Cronbach's alpha, the study found the reliability of all thirty-nine variables was .76. To assess the overall significance of the correlation matrix, the Bartlett's test of sphericity was measured. The Bartlett test shows that nonzero correlations existed at the significance level of .000. The Kaiser-Meyer-Olkin (KMO) was measured for the sampling adequacy (MSA). The result demonstrates that the set of variables collectively met the necessary threshold of sampling adequacy with an MSA value of .863. Thus, the set of variables met the fundamental requirements for factor analysis.

To identify the adoption characteristics, the study used factor analysis with varimax rotation as an extraction method. Although the factor loadings of . 30 could be considered for the factor due to the large sample size, this study considered .60 as a cut-off point (see Hair et.al, 1998). From this procedure, eight factors with eigenvalue greater than 1 were identified (Table 2). The identified factors represented 56.15 per cent of the variance of the variables. The first factor, difficulty, consisted of eight variables with eigenvalue 8.26 (alpha $=0.88)$. The acceptable value of Cronbach's alpha can vary between 0.5 and 0.95 depending on the type of research (Peterson 1994). The second factor, trust, was loaded with three variables with eigenvalue 3.67 (alpha $=0.87$ ). The third factor, compatibility, contained five variables with eigenvalue 2.44 (alpha $=0.79$ ). The fourth factor, third party concerns, was loaded with four variables with eigenvalue 1.94 (alpha $=0.74)$. The fifth factor, human contact, contained two variables with eigenvalue $1.70(\mathrm{alpha}=0.74)$. The sixth factor labeled as social influence referring to the reference group was loaded with three variables with eigenvalue $1.46($ alpha $=0.74)$. The seventh factor referred to security and was loaded with two variables with eigenvalue $1.40(\mathrm{alpha}=0.54)$. The last factor labeled as PC skills consisted of two variables with eigenvalue 1.07 (alpha $=0.54$ ). The first factor, difficulty, explained most of the total variance ( 21.18 per cent).

\subsubsection{Internal Consistency}

In the next step, an internal consistency evaluation was performed by measuring the item-to-total correlation (the correlation of the item to the summated scale score). Inter-item correlations within each summated scale score (the correlations among items) were also measured. The rule of thumb was that the scale was considered reliable when the internal consistency for the item-to-total correlation was above .50 and the inter-item correlation was above .30 (see Hair et al., 1998). All the correlations of the items to the summated scale scores were above .50 (at the .01 level) and all the inter-item correlations within each summated score were above .30 (at the .01 level). 
Thus, the items used for each construct met the requirements of reliability.

\subsubsection{Development of Hypotheses}

Previous research indicates the mixed results of the relationship between online banking and the characteristics of adoption. Many studies show that in general ease of use (Moutinho and Smith, 2000; Mattila et al., 2003; Wang et al., 2003), compatibility (Gurau, 2002), trust (Rotchanakitumnuai and Speece, 2003), reference group influence (Karjaluoto et al., 2002) and computer experience (Wang et al., 2003) had positive relationships with the adoption of online banking. Also, some studies found that security (Liao and Cheung, 2002; Rotchanakitumnuai and Speece, 2003), third-party concerns, and human contact (Gurau, 2002; Mattila et al., 2003) were negatively related to the adoption of online banking. Using Gerrard and Cunningham (2003) as a guide, the following hypotheses were formulated to test for the study.

H1: Adopters and non-adopters differed on the basis of their opinions about IB. As compared to non-adopters, adopters rated IB as being more trustworthy $(H l a)$, more compatible $(H 1 b)$, more in line with their reference group influence such as peers and co-workers, $(H 1 c)$, and requiring a high-level of PC skills (H1d).

H2: As compared to non-adopters, adopters rated IB as being less difficult $(H 2 a)$, they are less concerned about third-party issues $(\mathrm{H} 2 \mathrm{~b})$, require less human or physical contact $(\mathrm{H} 2 \mathrm{c})$, and are less concerned about security $(H 2 d)$.

\section{Results}

To test the hypotheses, an analysis of variance (ANOVA) was used to compare the means of the eight factors (difficulty, trust, compatibility, third-party concerns, human contact, reference group influence, security and PC skills) of characteristics of the adoption of online banking. The means and standard deviations of these factors are presented in Table 3.

\subsection{Hypotheses Testing}

The ANOVA results show that there were significant differences at the .01 level on four factors: difficulty, trust, compatibility and human contact (Table 4). On the difficulty attribute, the result shows that adopters had a lower mean compared to that of the non-adopters, suggesting that adopters believed that using online banking was not difficult. As compared to non-adopters, adopters rated higher scores on the factors of trust and compatibility. However, non-adopters perceived that human contact was a very important element for banking services. Thus, these results supported hypotheses $1 \mathrm{a}, 2 \mathrm{a}, 1 \mathrm{~b}$, and $2 \mathrm{c}$.

The results establish that there were no significant differences on four factors (third-party concerns, reference groups, security, and PC skills). In summary, adopters and non-adopters had similar perceptions about these four attributes. Thus, hypotheses $1 \mathrm{c}, 1 \mathrm{~d}, 2 \mathrm{~b}$, and $2 \mathrm{~d}$ were not supported. Table 5 shows the statistical t-test for each variable and Table 6 summarizes the hypotheses testing.

\section{Discussion}

This study examined the characteristics of the adoption of online banking of Mexican consumers. The study shows that eight factors defined these characteristics: Difficulty, trust, compatibility, third-party concerns, human contact, reference group influence, security and PC skills. Of these eight factors, the results show statistically significant differences on the adoption between adopters and non-adopters on four factors (difficulty, trust, compatibility and human contact). We elaborate on these results below.

\subsection{Difficulty}

Ease of use is an influential factor for the adoption of online banking. This factor has been identified by many studies. Moutinho and Smith (2000) and Wang et al., (2003) found evidence that perceived ease of use had a significant impact on the intention to adopt online banking. Mattila et al., (2003) examined the perception of mature consumers in Finland and reported that these consumers' perception of the difficulty of using online banking was the main barrier. This study found that difficulty was the most important attribute for the adoption of online banking in Mexico. Adopters found that using online banking was neither difficult nor complicated. This makes sense because in general we found online banking adopters to be innovative consumers and to be risk takers. Adopters are eager to learn about new products. Since they have learned about new products, they are familiar with them, eliminating the difficulty of using the innovations. This study shows that non-adopters rated online banking as difficult, complicated and confusing. As compared to adopters, non-adopters are not innovative consumers, and they usually do not buy new products at the introduction stage of the product life cycle. Because IB is still considered new for the majority of consumers in Mexico, it may take time for non-adopters to familiarize themselves with this new product and to adopt online banking. Also, the study found that non-adopters felt that IB transactions involved complex procedures. This perception may reduce the chance for non-adopters to adopt online banking.

\subsection{Trust}

Trust is considered an important aspect for the adoption of online banking because it can increase the rate of adoption. Rotchanakitumnuai and Speece (2003) used the qualitative approach to examine Thai corporate 
consumers and their study reported that non-adopters did not trust the financial transactions made via internet channels. They also found that non-adopters tended to have a negative attitude toward online adoption. The results of this study identified trust as the second characteristic for the adoption of online banking in Mexico. Adopters trusted both the ability of the banks to protect their privacy and the technology the banks were using. Non-adopters perceived online banking as risky. They did not trust the technology the banks were using and non-adopters did not believe that the banks could protect their privacy when they used the online service.

\subsection{Compatibility}

Online banking provides many advantages to both individual consumers and corporate consumers. Some advantages identified by Gurau's study (2002) were the reduced costs in accessing and using the banking services and the increased comfort and time-savings.

This study shows that compatibility was also an important attribute for the adoption of online banking. The study indicated that adopters preferred innovation and felt that using e-banking was compatible with their life style. Convenience, twenty four hour availability of IB, and ease of conducting transactions at home were important benefits for IB mentioned by adopters. Although this study shows that adopters and non-adopters perceived the compatibility issue differently, non-adopters agreed that e-banking could be compatible with their lifestyle. Non-adopters realized that e-banking could provide them with many benefits.

\subsection{Third Party Concerns}

The fourth characteristic found in this study was third party concerns. Although adopters have been using online services, they were still concerned about e-banking. Adopters were afraid that other people might be able to access their bank accounts or to track their bank usage. Adopters also were worried that their financial transactions might be passed to other companies in the bank's group. In addition, adopters and non-adopters showed no difference on their perceptions toward the issue of third party concerns.

\subsection{Human Contact}

In general, human or physical contact is a major element of any service business. There is a contrast between adopters and non-adopters on this factor. It makes sense that customers who use the online service were more likely to require less or no physical interaction with the bank. This has been evidenced from a previous study (Gurau, 2002). On the other hand, the lack of human contact or personal service in e-banking was the main barrier for online adoption (Mattila et al., 2003). Bank customers who need face to face interaction are more likely not to adopt online banking. Thus, the absence of this element will discourage bank customers from adopting IB. Adopters and non-adopters differ on this basis. Our study shows that non-adopters considered human or personal contact one of the most important attributes. This could be considered a limitation or weakness of online banking from the non-adopters' point of view.

\subsection{Reference Group Influence}

Literature on consumer behavior suggests that reference groups affect consumer behavior.

Karjaluoto et al. (2002) explored the effect of different factors affecting attitude formation toward IB in Finland. Their study identified reference group influence as one of the factors, showing that a bank's personnel and reference group influenced online banking behavior. We found the same result. All variables on this factor had a high factor loading above .70. However, the study shows that there was no significant difference on the perception toward reference group influence between adopters and non-adopters. Among reference groups, colleagues and peers produced the highest impact on the adoption of online banking.

\subsection{Security}

The intention of usage of IB can be affected by users' perceptions of credibility regarding security concerns. Previous studies suggested that security concerns affected the adoption of online banking (Liao and Cheung, 2002). Rotchanakitumnuai and Speece (2003) used the qualitative approach to examine Thai corporate consumers and their study reported that security was the main barrier to the adoption of e-banking. Studying the adoption of IB of Australian consumers, Sathye (1999) identified security concerns as the main obstacle to non-adoption. This study provided the same result as the previous studies.

An interesting finding of this study was that adopters were still concerned about the security issue although they had already used the online service. We found that adopters and non-adopters did not differ in their attitudes toward security.

\subsection{PC Proficiency}

Previous studies confirmed that computer self-efficacy played a critical role in understanding individual responses to information technology (Agarwal et al., 2000; Johnson and Marakas, 2000; Chau, 2001; Hong et al., 2001).Wang et al., (2003) extend the technology acceptance model (TAM) to understand the intention of people to adopt IB. Their study indicated that the individual differences in computer self-efficacy produced significantly positive effects on the behavioral intention to adopt IB through perceived usefulness and ease of use. Gerrard and Cunningham (2003) studied the characteristics of online banking in Singapore and found that computer 
experience or computer proficiency was an influential factor for adoption. This study shows that both adopters and non-adopters agreed that a lack of computer skills discouraged IB usage.

\section{Conclusions and Implications}

This study provides many benefits to bank managers. There are many issues that bank managers should consider for their customers who already have online accounts. The study shows that these online customers were still worried about the following issues: Trust, third-party concerns, and security. Banks should be aware of these issues because customers may stop using the banks' online services if they feel insecure about using IB. Communication will be the key to solving these problems. Banks may need to communicate with their customers and convince them that using online banking is safe and secure. Banks need to build their customers confidence about the technology the banks use for the online service. Media such as brochures or newsletters from the banks may be used to communicate with their customers. The banks' websites also help to inform their customers about online security. Banks could also use websites to alert their customers about any fraud that may happen in the future.

Non-adopters are potential customers for online banking. Bank managers need to do strategic marketing planning as to how to capture this segment. Our study shows that non-adopters felt that ease of use or the difficulty of using online banking was a significant problem for them. Non-adopters felt that using IB was complicated, difficult to understand, and not easy. Banks should consider training and education programs that will help customers overcome the difficulty of using online banking. Banks should employ training and promotional approaches to develop the customers' beliefs in the usefulness and ease of the system, which in turn will influence the behavioral intention to adopt IB services. A limited trial period for online banking may be offered to these potential customers.

Another issue raised by the non-adopters was about the bank's webpage. These nonusers mentioned that the webpage was confusing and that it was difficult for them to conduct transactions online. A customer-focused approach is needed for adapting the website to the skills of users. Appropriate training of the bank personnel and intensive educational programs about online banking may be provided to the non-adopters. Banks can also demonstrate how to use its website online to its potential customers. Also, banks need to focus on the design of their web page to insure that the web page is uncomplicated, and friendly or easy to use.

Trust, security and third-party concerns were important attributes from the perception of non-adopters. In this case, banks need to build confidence about e-banking. The objective of the bank on the security and trust issues must be clear and a first-priority. The bank must inform its customers about its security policy through all available media such as its website, brochures or newsletters.

\section{Future Research}

Although this study identified the adoption characteristics of online banking for adopters and non-adopters in Mexico, the sample used for the study was from a specific geographic area of Mexico. Thus, generalization of this study, to some extent, is limited. Whether the adoption characteristics of online banking identified from this study will be a norm for those in other parts of the country is an interesting avenue for future research.

This study did not fully investigate the issue of demographics of adopters and non-adopters. Whether the demographics of the online users will play an important role in the adoption of online banking is interesting. Also, knowing the demographics of both adopters and non-adopters in Mexico will benefit the financial institutions. Banks can use the demographic data to identify a target segment for their prospective online users.

An interesting finding was that security was still an important factor perceived by both adopters and non-adopters. We found that their perceptions toward the issue of security were about the same. Qualitative methods such as focus groups and intensive interviews should be used in future research to learn more about the Mexican consumer perceptions toward the issue of security.

\section{References}

Akinci, S., Aksoy S., and Atilgan, E. (2004). Adoption of Internet Banking among Sophisticated Consumer Sements in an Advanced Developing Country. International Journal of Bank Marketing, 22 (3), 212-232. doi:10.1108/02652320410530322, http://dx.doi.org/10.1108/02652320410530322

Agarwal, R., Sambamurthy, V., and Stair, R.M. (2000). Research Report: the Evolving Relationship between General and Specific Computer Self-Efficacy-an Empirical Assessment. Information Systems Research, 11 (4), 418-30. doi:10.1287/isre.11.4.418.11876, http://dx.doi.org/10.1287/isre.11.4.418.11876

Black, N.J., Lockett, A., Winklhofer, H., and Ennew, C. (2001). The Adoption of Internet Financial Services: A Qualitative Study. International Journal of Retail and Distribution Management, 29 (8), 390-398. doi:10.1108/09590550110397033, http://dx.doi.org/10.1108/09590550110397033

Bagozzi, R.P. (2000). On the Concept of International Scale Action in Consumer Behavior. Journal of Consumer Research, 27 (3), 388-96. doi:10.1086/317593, http://dx.doi.org/10.1086/317593

Business News Americas. (2003). Bancomer Holds 33\% Stake in e-Banking (October 24). [Online] Available: 
http://www.bnamericas.com/

Business News Americas. (2005). Banamex Plans Online Services Charge (January 5). [Online] Available: http://www.bnamericas.com/

Chau, P.Y.K. (2001). Influence of Computer Attitude and Self-Efficacy on IT Usage Behavior. Journal of End User Computing, 13 (1), 26-33. doi:10.4018/joeuc.2001010103, http://dx.doi.org/10.4018/joeuc.2001010103

Chou, D., and Chou, A.Y. (2000). A Guide to the Internet Revolution in Banking. Information Systems Management, $\quad 17$ (2), 51-7. doi:10.1201/1078/43191.17.2.20000301/31227.6, http://dx.doi.org/10.1201/1078/43191.17.2.20000301/31227.6

Cooper, R.G. (1997). Examining Some Myths about New Product Winners," In Katz, R. (Ed.), The Human Side of Managing Technological Innovation (pp.550-60). Oxford.

Corporate Mexico. (2003). BBVA Online Operations Increase 120\% (May 15).

Daniel, E. (1999). Provision of Electronic Banking in the UK and the Republic of Ireland. International Journal

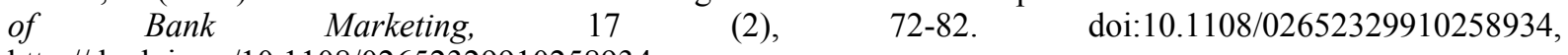
http://dx.doi.org/10.1108/02652329910258934

Eriksson, K., Kerem, K., and Daniel, N. (2005). Customer Acceptance of Internet Banking in Estonia. International Journal of Bank Marketing, 23 (2), 200-16. doi:10.1108/02652320510584412, http://dx.doi.org/10.1108/02652320510584412

Fishbein, M. and Ajzen, I. (1975). Belief, Attitude, Intention and Behavior: An Introduction to Theory and Research. Addison-Wesley, Reading, MA.

Gerrard, P., and Cunningham, J.B. (2003). The Diffusion of Internet Banking among Singapore consumers. International Journal of Bank Marketing, 21 (1), 16-28. doi:10.1108/02652320310457776, http://dx.doi.org/10.1108/02652320310457776

Gurau, C. (2002). Online Banking in Transition Economies: the Implementation and Development of Online Banking Systems in Romania. International Journal of Bank Marketing, 20(6), 285-96. doi:10.1108/02652320210446742, http://dx.doi.org/10.1108/02652320210446742

Hair, J.F., Anderson, R.E., Tatham, R.L., and Black, W.C. (1998). Multivariate Data Analysis (5 ${ }^{\text {th }}$ ed.). Prentice-Hall, Upper Saddle River, NJ.

Hong, W., Thong, J.Y.L., Wong, W.M., and Tam, K.Y. (2001). Determinants of User Acceptance of Digital Libraries: An Empirical Examination of Individual Differences and System Characteristics. Journal of Management Information Systems, 18(3), 97-124.

Johnson, R.D., and Marakas, G.M. (2000). Research Report: the Role of Behavior Modeling in Computer Skills Acquisition-Toward Refinement of the Model. Information Systems Research, 11(4), 402-417. doi:10.1287/isre.11.4.402.11869, http://dx.doi.org/10.1287/isre.11.4.402.11869

Karjaluoto, Heikki, Mattila Minna, and Tapio Pento. (2002). Factors underlying attitude towards online banking in Finland. International Journal of Bank Marketing, 20 (6), 261-272. doi:10.1108/02652320210446724, http://dx.doi.org/10.1108/02652320210446724

Lassar, Walfried M., Manolis Chris and Sharon S. Lassar. (2005). The Relationship between Consumer Innovativeness Personal Characteristics, and Online Banking Adoption. International Journal of Bank Marketing, 23 (2), 176-199. doi:10.1108/02652320510584403, http://dx.doi.org/10.1108/02652320510584403

Liao, Z. and Cheung, M.T. (2002). Internet-Based e-Banking and Consumer Attitudes: An empirical Study. Information \& Management, 39 (4), 283-95. doi:10.1016/S0378-7206(01)00097-0, http://dx.doi.org/10.1016/S0378-7206(01)00097-0

Mattila, M., Karjaluoto, H., and Tapio Pento. (2003). Internet Banking Adoption among Mature Customers: Early Majority or Laggards?. Journal of Services Marketing, 17(5), 514-28. doi:10.1108/08876040310486294, http://dx.doi.org/10.1108/08876040310486294

Moutinho, L., and Smith, A. (2000). Modeling Bank Customers'Satisfaction through Mediation of Attitudes towards Human and Automated Banking. International Journal of Bank Marketing, 18 (3), 124-34. doi:10.1108/02652320010339699, http://dx.doi.org/10.1108/02652320010339699

O'Connell, B. (1996). Australian Banking on the Internet-Fact or Fiction?. The Australian Banker, December, p.212-14.

Peterson, R.A. (1994). A Meta-Analysis of Cronbach's Coefficient Alpha. Journal of Consumer Research, 21 (2), 381-91. doi:10.1086/209405, http://dx.doi.org/10.1086/209405

Pikkarainen, T., Pikkarainen K., Karjaluoto, H., and Seppo, P. (2004). Consumer Acceptance of Online Banking: an Extension of the Technology Acceptance model. Internet Research, 14 (3), 224-35. doi:10.1108/10662240410542652, http://dx.doi.org/10.1108/10662240410542652 
Polasik, K., and Wisniewski, T. (2009). Empirical Analysis of Internet Banking Adoption in Poland. International Journal of Bank Marketing, 27 (1), 32-52. doi:10.1108/02652320910928227, http://dx.doi.org/10.1108/02652320910928227

Rogers, E.M. (1962). The Diffusion of Innovations $\left(1^{\text {st }}\right.$ ed.). The Free Press, New York, NY.

Rogers, E.M. (1983). The Diffusion of Innovations ( $3^{\text {rd }}$ ed.). The Free Press, New York, NY.

Rogers, E.M. (1995). The Diffusion of Innovations ( $4^{\text {th }}$ ed.). The Free Press, New York, NY.

Rotchanakitumnuai S, and Speece, M. (2003). Barriers to Internet Banking Adoption: A Qualitative Study among Corporate Customers in Thailand. International Journal of Bank Marketing, 21 (6/7), 312-23. doi:10.1108/02652320310498465, http://dx.doi.org/10.1108/02652320310498465

Sathye, M. (1999). Adoption of Internet Banking by Australian Consumers: An Empirical Investigation. International Journal of Bank Marketing, 17(7), 324-334. doi:10.1108/02652329910305689, http://dx.doi.org/10.1108/02652329910305689

Waite, K., and Harrison, T. (2002). Consumer Expectations of Online Information Provided by Bank Websites. Journal of Financial Services Marketing, 6 (4), 309-322. doi:10.1057/palgrave.fsm.4770061, http://dx.doi.org/10.1057/palgrave.fsm.4770061

Waite, K., and Harrison T. (2004). Online banking information: what we want and what we get. Qualitative Market Research: An International Journal, 7 (1), 67-79. doi:10.1108/13522750410512895, $\mathrm{http}: / / \mathrm{dx}$.doi.org/10.1108/13522750410512895

Wallsten, S. (2005). Regulation and Internet Use in Developing Countries. Economic Development and Cultural Change, 53 (2), 501-23. doi:10.1086/425376, http://dx.doi.org/10.1086/425376

Wang, Y., Wang, Y., Lin, H., and Tang, T. (2003). Determinants of User Acceptance of Internet Banking: An Empirical Study. International Journal of Service Industry Management, 14 (5), 501-19. doi:10.1108/09564230310500192, http://dx.doi.org/10.1108/09564230310500192

White, H., and Nteli, F. (2004). Internet Banking in the UK: Why Are There Not More Customers?. Journal of Financial Services Marketing, 9 (1), 49-56. doi:10.1057/palgrave.fsm.4770140, http://dx.doi.org/10.1057/palgrave.fsm.4770140 
Table 1. Profile of respondents and their internet uses

\begin{tabular}{|c|c|c|c|c|}
\hline & Frequency & Percent & Valid percent & Cumulative percent \\
\hline Gender & & & & \\
\hline Female & 170 & 46.6 & 47.4 & 47.4 \\
\hline Male & 189 & 51.8 & 52.6 & 100.0 \\
\hline Missing & 6 & 1.6 & & \\
\hline Total & 365 & 100.0 & & \\
\hline Age & & & & \\
\hline $20-25$ & 132 & 36.2 & 36.2 & 36.2 \\
\hline $26-30$ & 83 & 22.7 & 22.7 & 58.9 \\
\hline $31-35$ & 52 & 14.2 & 14.2 & 73.2 \\
\hline $36-40$ & 32 & 8.8 & 8.8 & 81.9 \\
\hline Above 40 & 66 & 18.1 & 18.1 & 100.0 \\
\hline Total & 365 & 100.0 & 100.0 & \\
\hline Marital status & & & & \\
\hline Married & 139 & 38.1 & 39.4 & 39.4 \\
\hline Not married & 214 & 58.6 & 60.6 & 100.0 \\
\hline Missing & 12 & 3.3 & & \\
\hline Total & 365 & 100.0 & 100.0 & \\
\hline Education & & & & \\
\hline High school & 54 & 14.8 & 15.3 & 15.3 \\
\hline College degree & 199 & 54.5 & 56.4 & 71.9 \\
\hline Master degree & 92 & 52.2 & 26.1 & 89.0 \\
\hline Doctoral degree & 7 & 1.9 & 2.0 & 100.0 \\
\hline Missing & 13 & 3.6 & & \\
\hline Total & 365 & 100.0 & & \\
\hline $\begin{array}{l}\text { Household income } \\
\text { per month(Peso) }\end{array}$ & & & & \\
\hline Below 10,000 & 166 & 45.5 & 47.0 & 47.0 \\
\hline $10,001-20,000$ & 94 & 25.8 & 26.6 & 73.6 \\
\hline $20,001-30,000$ & 38 & 10.4 & 10.7 & 84.3 \\
\hline $30,001-40,000$ & 24 & 6.6 & 6.8 & 91.1 \\
\hline Above 40,000 & 31 & 8.5 & 8.8 & 100.0 \\
\hline Missing & 12 & 3.2 & & \\
\hline Total & 365 & 100.0 & & \\
\hline Have computer at home & & & & \\
\hline Yes & 328 & 89.8 & 90.1 & 90.1 \\
\hline No & 36 & 9.8 & 9.9 & 100 \\
\hline Missing & 1 & 0.3 & & \\
\hline Total & 365 & 100.0 & & \\
\hline Have internet at home & & & & \\
\hline Yes & 294 & 80.5 & 80.5 & 80.5 \\
\hline No & 71 & 19.5 & 19.5 & 100 \\
\hline Total & 365 & 100.0 & & \\
\hline Have computer at work & & & & \\
\hline Yes & 343 & 94.0 & 97.2 & 97.2 \\
\hline No & 10 & 2.7 & 2.8 & 100.0 \\
\hline Missing & 12 & 3.7 & & \\
\hline Total & 365 & 100 & & \\
\hline
\end{tabular}


Table 1. Profile of respondents and their internet uses (continued)

\begin{tabular}{|l|l|l|l|l|}
\hline & Frequency & Percent & Valid percent & Cumulative percent \\
\hline Have internet at work & & & & \\
Yes & 329 & 90.0 & 94.0 & 94.0 \\
No & 21 & 5.8 & 6.0 & 100.0 \\
Missing & 15 & 4.1 & & \\
Total & 365 & $100 / 0$ & & \\
Number of months using & & & & \\
internet & & & & \\
Less than 6 months & 6 & 1.6 & 1.6 & 1.6 \\
6-12 months & 7 & 1.9 & 1.9 & 3.6 \\
$1-3$ years & 46 & 12.6 & 12.6 & 16.2 \\
$4-6$ years & 115 & 31.5 & 31.6 & 47.8 \\
7 years or more & 190 & 52.1 & 52.2 & 100.0 \\
Missing & 1 & 0.3 & & \\
Total & 365 & 100.0 & & \\
Number of hours a week & & & & \\
using internet & & & & \\
Less than 1 hour & 25 & 6.8 & 6.9 & 6.9 \\
1-5 hours & 95 & 26.0 & 26.1 & 33.0 \\
6-10 hours & 79 & 21.6 & 21.7 & 54.7 \\
11-20 hours & 56 & 15.3 & 15.4 & 70.1 \\
21-40 hours & 59 & 16.2 & 16.2 & 86.3 \\
Over 40 hours & 50 & 13.7 & 13.7 & 100.0 \\
Missing & 1 & 0.3 & & \\
Total & 365 & 100.0 & & \\
Internet access & & & \\
Home & 58 & 15.9 & 15.9 & 15.9 \\
Office & 144 & 39.5 & 39.5 & 55.3 \\
Both home and office & 158 & 43.3 & 43.3 & 98.6 \\
Others & 5 & 1.4 & 1.4 & 100.0 \\
Total & 365 & 100.0 & & \\
\hline
\end{tabular}


Table 2. Factor underlying adoption characteristics

\begin{tabular}{|c|c|c|c|c|c|c|c|c|}
\hline & F1 & F2 & F3 & F4 & F5 & F6 & F7 & F8 \\
\hline \multicolumn{9}{|l|}{ Difficulty } \\
\hline 1. Using internet requires a lot of effort & .79 & & & & & & & \\
\hline 2. Use of computer or/and internet is difficult & .72 & & & & & & & \\
\hline 3. IB Web pages are confusing & .70 & & & & & & & \\
\hline 4. Using IB can be complicated & .69 & & & & & & & \\
\hline 5. Using IB is difficult to understand & .65 & & & & & & & \\
\hline 6. IB transactions involve with complex procedures & .64 & & & & & & & \\
\hline 7. IB is only for computer experts & .62 & & & & & & & \\
\hline 8. IB is a difficult way to conduct baking transactions & .60 & & & & & & & \\
\hline \multicolumn{9}{|l|}{ Trust } \\
\hline $\begin{array}{l}\text { 1.I trust in the ability of an internet bank to protect my } \\
\text { privacy }\end{array}$ & & .83 & & & & & & \\
\hline $\begin{array}{l}\text { 2. I trust in the technology an internet bank is using } \\
\text { 3. Using an internet bank is financially secure }\end{array}$ & & $\begin{array}{l}.82 \\
.79\end{array}$ & & & & & & \\
\hline \multicolumn{9}{|l|}{ Compatibility } \\
\hline 1. I like innovations & & & .74 & & & & & \\
\hline 2. IB is compatible with my lifestyle & & & .68 & & & & & \\
\hline 3. Using IB fits into my working style & & & .66 & & & & & \\
\hline 4. IB enables transactions to be conducted at home & & & .64 & & & & & \\
\hline 5. IB provides convenience since it is available 24 hours & & & .64 & & & & & \\
\hline \multicolumn{9}{|l|}{ Third Party Concerns } \\
\hline $\begin{array}{l}\text { 1. Third party may be able to access my financial details } \\
\text { on the internet }\end{array}$ & & & & .77 & & & & \\
\hline $\begin{array}{l}\text { 2. Third party may track my bank usage patterns on the } \\
\text { internet }\end{array}$ & & & & .76 & & & & \\
\hline $\begin{array}{l}\text { 3. Hackers may be able to gain access to internet bank } \\
\text { accounts }\end{array}$ & & & & .69 & & & & \\
\hline $\begin{array}{l}\text { 4. Customer financial affairs may be passed on to other } \\
\text { companies in the bank group }\end{array}$ & & & & .62 & & & & \\
\hline \multicolumn{9}{|l|}{ Human Contact } \\
\hline $\begin{array}{l}\text { 1. Face to face interaction is important for bank service } \\
\text { 2. Absence of human element discourage internet bank } \\
\text { usage }\end{array}$ & & & & & $\begin{array}{l}.75 \\
.66\end{array}$ & & & \\
\hline \multicolumn{9}{|l|}{ Reference Group Influence } \\
\hline $\begin{array}{l}\text { 1. My decision to adopt IB is influenced by my } \\
\text { colleagues and peers }\end{array}$ & & & & & & .83 & & \\
\hline $\begin{array}{l}\text { 2. My decision to adopt IB is influenced by my friends } \\
\text { 3. My decision to adopt IB is influenced by my family }\end{array}$ & & & & & & $\begin{array}{l}.80 \\
.70\end{array}$ & & \\
\hline \multicolumn{9}{|l|}{ Security } \\
\hline 1. I am worried about the security of an internet bank & & & & & & & .64 & \\
\hline $\begin{array}{l}\text { 2. Matters of security have an influence on using an } \\
\text { internet bank }\end{array}$ & & & & & & & .61 & \\
\hline \multicolumn{9}{|l|}{ PC Skills } \\
\hline 1. Inadequate PC skills discourage interne bank usage & & & & & & & & .75 \\
\hline $\begin{array}{l}\text { 2. Upgrade browser software discourage internet bank } \\
\text { usage }\end{array}$ & & & & & & & & .72 \\
\hline Eigen values & 8.26 & 3.67 & 2.44 & 1.94 & 1.70 & 1.46 & 1.40 & 1.07 \\
\hline$\%$ variance & 21.18 & 9.24 & 6.27 & 4.97 & 4.36 & 3.74 & 3.59 & 2.76 \\
\hline Cumulative variance & 21.18 & 30.43 & 36.70 & 41.68 & 46.04 & 49.79 & 53.38 & 56.15 \\
\hline Cronbach Alphas & .88 & .87 & .79 & .74 & .74 & .74 & .54 & .54 \\
\hline
\end{tabular}


Table 3. A comparison of adopters and non-adopters on the characteristics of adoption

\begin{tabular}{|l|l|l|l|l|l|l|}
\hline & \multicolumn{2}{|c|}{ All } & \multicolumn{2}{c|}{ Adopters } & \multicolumn{3}{c|}{ Non-adopters } \\
\hline & Mean & Std & Mean & Std & Mean & Std \\
\hline Adoption characteristics & & & & & & \\
Difficulty & 2.20 & .72 & 2.08 & .67 & 2.44 & .78 \\
Trust & 3.27 & .92 & 3.49 & .85 & 2.80 & .90 \\
Compatibility & 4.13 & .65 & 4.28 & .56 & 3.82 & .73 \\
Third Party Concerns & 3.27 & .89 & 3.24 & .86 & 3.34 & .96 \\
Human Contact & 2.92 & 1.03 & 2.76 & 1.03 & 3.29 & .94 \\
Reference Group & 2.22 & .90 & 2.22 & .94 & 2.21 & .81 \\
Security & 3.96 & .82 & 3.96 & .83 & 3.95 & .80 \\
PC Proficiency & 3.48 & .86 & 3.50 & .88 & 3.45 & .82 \\
\hline
\end{tabular}

Note: 5 indicate strongly agree on the likert scale; 1 indicates strongly disagree on the likert scale

Table 4. Analysis of variance (ANOVA)

\begin{tabular}{|c|c|c|c|c|c|c|}
\hline & & $\begin{array}{l}\text { Sum of } \\
\text { Squares }\end{array}$ & df & Mean Squares & $\mathbf{F}$ & Sig. \\
\hline $\begin{array}{l}\text { Adoption } \\
\text { characteristics } \\
\text { Difficulty }\end{array}$ & $\begin{array}{l}\text { Between Groups } \\
\text { Within Groups } \\
\text { Total }\end{array}$ & $\begin{array}{c}9.593 \\
172.005 \\
181.598 \\
\end{array}$ & $\begin{array}{c}1 \\
341 \\
342 \\
\end{array}$ & $\begin{array}{c}9.593 \\
.504\end{array}$ & 19.017 & $.000 * *$ \\
\hline Trust & $\begin{array}{l}\text { Between Groups } \\
\text { Within Groups } \\
\text { Total }\end{array}$ & $\begin{array}{c}36.398 \\
270.478 \\
306.876 \\
\end{array}$ & $\begin{array}{c}1 \\
355 \\
356 \\
\end{array}$ & $\begin{array}{c}36.398 \\
.762\end{array}$ & 47.772 & $.000 * *$ \\
\hline Compatibility & $\begin{array}{l}\text { Between Groups } \\
\text { Within Groups } \\
\text { Total }\end{array}$ & $\begin{array}{c}16.148 \\
137.177 \\
153.326 \\
\end{array}$ & $\begin{array}{c}1 \\
353 \\
354 \\
\end{array}$ & $\begin{array}{c}16.148 \\
.389\end{array}$ & 41.555 & $.000 * *$ \\
\hline $\begin{array}{l}\text { Adoption } \\
\text { characteristics } \\
\text { Third Party Concerns }\end{array}$ & $\begin{array}{l}\text { Between Groups } \\
\text { Within Groups }\end{array}$ & $\begin{array}{c}.692 \\
274.995 \\
\end{array}$ & $\begin{array}{c}1 \\
340 \\
\end{array}$ & $\begin{array}{l}.692 \\
.809 \\
\end{array}$ & .856 & .356 \\
\hline & Total & 275.687 & 341 & & & \\
\hline Human Contact & Between Groups & 21.407 & 1 & 21.407 & 21.029 & $.000 * *$ \\
\hline & Within Groups & 357.322 & 351 & .018 & & \\
\hline & Total & 378.729 & 352 & & & \\
\hline Reference Group & Between Groups & .027 & 1 & .027 & .032 & .857 \\
\hline & Within Groups & 293.492 & 358 & .820 & & \\
\hline & Total & 293.518 & 359 & & & \\
\hline Security & Between Groups & .017 & 1 & .017 & .026 & .873 \\
\hline & Within Groups & 237.713 & 349 & .681 & & \\
\hline & Total & 237.731 & 350 & & & \\
\hline PC Proficiency & Between Groups & .213 & 1 & .213 & .282 & .282 \\
\hline & Within Groups & 266.981 & 354 & .754 & & \\
\hline & Total & 267.193 & 355 & & & \\
\hline
\end{tabular}

Note: $* *$ significant at $\mathrm{p}<0.01$ 
Table 5. Comparisons of characteristics of adoption ranked by the mean scores of adopters

\begin{tabular}{|c|c|c|c|c|c|}
\hline & $\begin{array}{l}\text { Adopters } \\
\text { Mean }\end{array}$ & $\begin{array}{l}\text { Non-adopters } \\
\text { Mean }\end{array}$ & t-stat. & DF & $\begin{array}{c}\text { Sig. } \\
\text { (two-tailed) }\end{array}$ \\
\hline $\begin{array}{l}\text { 1. IB enables transactions to be } \\
\text { conducted at home (Compatibility) }\end{array}$ & 4.54 & 4.17 & 4.123 & 359 & $.000^{* *}$ \\
\hline $\begin{array}{l}\text { 2. IB provides convenience since it is } \\
\text { available } 24 \text { hours (Compatibility) }\end{array}$ & 4.39 & 3.99 & 3.992 & 359 & $.000 * *$ \\
\hline $\begin{array}{l}\text { 3. IB is compatible with my lifestyle } \\
\text { (Compatibility) }\end{array}$ & 4.26 & 3.46 & 7.582 & 359 & $.000^{* *}$ \\
\hline 4. I like innovations (Compatibility) & 4.24 & 3.96 & 2.993 & 359 & $.003 * *$ \\
\hline $\begin{array}{l}\text { 5. I am worried about the security of an Internet } \\
\text { bank (Security) }\end{array}$ & 3.99 & 4.09 & -.885 & 359 & .377 \\
\hline $\begin{array}{l}\text { 6. Using IB fits into my working style } \\
\text { (Compatibility) }\end{array}$ & 3.96 & 3.54 & 3.948 & 358 & $.000 * *$ \\
\hline $\begin{array}{l}\text { 7. Matters of security have an influence on using } \\
\text { an Internet bank (Security) }\end{array}$ & 3.95 & 3.82 & 1.105 & 351 & .270 \\
\hline $\begin{array}{l}\text { 8. Hackers may be able to gain access to Internet } \\
\text { bank accounts (Third Party Concerns) }\end{array}$ & 3.68 & 3.75 & -.513 & 349 & .608 \\
\hline $\begin{array}{l}\text { 9. I trust in the technology an Internet bank is } \\
\text { using (Trust) }\end{array}$ & 3.68 & 2.95 & 6.732 & 358 & $.000 * *$ \\
\hline $\begin{array}{l}\text { 10. Upgrade browser software discourage internet } \\
\text { bank usage (PC Proficiency) }\end{array}$ & 3.51 & 3.54 & .285 & 355 & .775 \\
\hline $\begin{array}{l}\text { 11. Inadequate PC skills discourage Internet bank } \\
\text { usage (PC Proficiency) }\end{array}$ & 3.49 & 3.35 & -1.208 & 360 & .228 \\
\hline $\begin{array}{l}\text { 12. I trust in the ability of an Internet bank to } \\
\text { protect my privacy (Trust) }\end{array}$ & 3.42 & 2.68 & 6.366 & 358 & $.000 * *$ \\
\hline $\begin{array}{l}\text { 13. Using an Internet bank is financially secure } \\
\text { (Trust) }\end{array}$ & 3.37 & 2.80 & 5.182 & 359 & $.000 * *$ \\
\hline $\begin{array}{l}\text { 14. Third party may track my bank usage patterns } \\
\text { on the internet (Third Party Concerns) }\end{array}$ & 3.20 & 3.37 & -1.218 & 355 & .224 \\
\hline $\begin{array}{l}\text { 15. Third party may be able to access my financial } \\
\text { details on the internet (Third Party Concerns) }\end{array}$ & 3.14 & 3.30 & -1.094 & 356 & .275 \\
\hline $\begin{array}{l}\text { 16. Customer financial affairs may be passed on to } \\
\text { other companies in the bank group (Third Party } \\
\text { Concerns) }\end{array}$ & 2.91 & 2.96 & -.326 & 354 & .745 \\
\hline $\begin{array}{l}\text { 17. Face to face interaction is important for bank } \\
\text { service (Human Contact) }\end{array}$ & 2.91 & 3.48 & -4.406 & 354 & $.000 * *$ \\
\hline $\begin{array}{l}\text { 18. Absence of human element discourages } \\
\text { Internet bank usage (Human Contact) }\end{array}$ & 2.62 & 3.12 & -3.893 & 357 & $.000^{* *}$ \\
\hline 19. IB Web pages are confusing (Difficulty) & 2.38 & 2.77 & -3.120 & 356 & $.002 * *$ \\
\hline $\begin{array}{l}\text { 20. My decision to adopt IB is influenced by my } \\
\text { colleagues and peers (Reference Group Influence) }\end{array}$ & 2.37 & 2.23 & -1.082 & 360 & .280 \\
\hline $\begin{array}{l}\text { 21. IB transactions involve with complex } \\
\text { procedures (Difficulty) }\end{array}$ & 2.35 & 2.75 & -3.221 & 357 & $.002 * *$ \\
\hline 22. Using IB can be complicated (Difficulty) & 2.32 & 2.65 & -2.715 & 358 & $.009 * *$ \\
\hline $\begin{array}{l}\text { 23. My decision to adopt IB is influenced by my } \\
\text { family (Reference Group Influence) }\end{array}$ & 2.23 & 2.23 & .012 & 359 & .990 \\
\hline 24. Using IB is difficult to understand (Difficulty) & 2.13 & 2.68 & -5.027 & 359 & $.000 * *$ \\
\hline $\begin{array}{l}25 . \text { IB is a difficult way to conduct baking } \\
\text { transactions (Difficulty) }\end{array}$ & 2.12 & 2.53 & -3.811 & 356 & $.000 * *$ \\
\hline $\begin{array}{l}\text { 26. My decision to adopt IB is influenced by my } \\
\text { friends (Reference Group Influence) }\end{array}$ & 2.09 & 2.22 & 1.135 & 359 & .257 \\
\hline 27. IB is only for computer experts (Difficulty) & 1.96 & 2.34 & -3.656 & 360 & $.001 * *$ \\
\hline $\begin{array}{l}\text { 28. Using internet requires a lot of effort } \\
\text { (Difficulty }\end{array}$ & 1.78 & 1.96 & -1.826 & 359 & $.069 *$ \\
\hline 29. Use of computer or/and internet is difficult & 1.69 & 1.86 & -1.665 & 358 & .103 \\
\hline
\end{tabular}

Notes: ** significant at $\mathrm{p}<0.01 ; *$ significant at $\mathrm{p}<.10$; Parentheses show the characteristics of the adoption of online banking. 
Table 6. Summary of hypotheses testing

\begin{tabular}{|c|c|}
\hline Hypothesis & Results \\
\hline H1a: As compared to non-adopters, adopters rated IB as being more trust. & Supported \\
\hline H1b: As compared to non-adopters, adopters rated IB as being more compatible. & Supported \\
\hline $\begin{array}{l}\text { H1c: As compared to non-adopters, adopters rated IB as being more influenced from } \\
\text { reference }\end{array}$ & Not Supported \\
\hline $\begin{array}{l}\text { H1d: As compared to non-adopters, adopters rated IB as requiring a higher level of PC } \\
\text { proficiency. }\end{array}$ & Not Supported \\
\hline H2a: As compared to non-adopters, adopters rated IB as being less difficulty. & Supported \\
\hline $\begin{array}{l}\text { H2b: As compared to non-adopters, adopters rated IB as being less concerned about third } \\
\text { party. }\end{array}$ & Not Supported \\
\hline $\begin{array}{l}\text { H2c: As compared to non-adopters, adopters rated IB as requiring less human or physical } \\
\text { contact. }\end{array}$ & Supported \\
\hline $\begin{array}{l}\text { H2d: As compared to non-adopters, adopters rated IB as being less concerned about } \\
\text { security. }\end{array}$ & Not Supported \\
\hline
\end{tabular}

